\title{
The Extent of Using Capital Budgeting Techniques in Evaluating Manager's Investments Projects Decisions (A Case Study on Jordanian Industrial Companies)
}

\author{
Osama Samih Shaban ${ }^{1}$, Ziad Al-Zubi ${ }^{1} \&$ Ahmad Adel Abdallah ${ }^{1}$ \\ ${ }^{1}$ Department of Accounting, Al-Zaytoonah University, Amman, Jordan \\ Correspondence: Dr. Osama Shaban, Department of Accounting, Al-Zaytoonah University, Amman, PO Box 130 \\ Amman 11733, Jordan. Tel: 962-798-793-473. E-mail: drosama@zuj.edu.jo
}

Received: September 20, 2017

Accepted: October 17, 2017

Online Published: November 15, 2017

doi:10.5539/ijef.v9n12p175

URL: https://doi.org/10.5539/ijef.v9n12p175

\begin{abstract}
The aim of this research paper is to study the extent of using capital budgeting techniques on choosing the suitable project for investment. The current research study focused on capital budgeting techniques such as Net Present Value NPV, and Internal Rate of Return IRR, and Pay Back period PB, which is considered the main tools in the hands of decision makers in deciding the best possible alternative of investment. In order to achieve the purposes of the study a questionnaire have been created (based on Graham and Harvey survey in 2001), the aim was to cover most of the Jordanian industrial companies despite of their size and ownership in the current year 2017. Resolution data were analyzed using the statistical program SSPS. Finally, the study concluded that, $58 \%$ of Jordanian industrial companies use the Net Present Value, 22\% use the Payback Period, 12\% use the Internal Rate of Return, and the remaining used a combination of the Accounting Rate of Return, Profitability Index, and sensitivity analysis. The current research study is expected to assess management in choosing the best capital budgeting technique in the evaluation of its future investment projects.
\end{abstract}

Keywords: capital budgeting techniques, internal rate of return, Jordanian industrial companies, net present value, pay back period

\section{Introduction}

The history of capital budgeting techniques used in determining the worth of projects or assets is rich and countless. Functioning capital budgeting is a must, not a choice. The success or failure of a business totally depends on the proper method of budgeting used. In other words the significance of the budgeting methods involves either profit or loss eventually. We can say that, the future of the project depends upon the capital budgeting decision taken by management, and the effectiveness of the method used. In other words management not only responsible for the growth of the company and maximizing it worth, but they are also responsible on behalf of the business organization in determining and evaluating the potential expenses or investments in projects or plant assets before it starts.

The importance of the current research study is derived from amounts of investment expected to be involved in the project, once these amounts are invested it will not be reversed without significant loss of the invested amounts. As earlier explained, not only the profitability of the project is on the stick, but also the future of the project is under risk of such a decision.

The aim of this research paper is to study the extent of using capital budgeting techniques on choosing the suitable project for investment. The current research study focused on capital budgeting techniques such as Net Present Value NPV, and Internal Rate of Return IRR, and Pay Back period PB, which is considered the main tools in the hands of decision makers in deciding the best possible alternative of investment.

In the current research paper we are going to illustrate and cover all of the various techniques used by managers in order to evaluate projects and judge their expected future value. In order to achieve this objective, Graham and Harvey survey in 2001 was adopted. The survey covers all types and sizes of firms despite of their size and ownership in the current year 2017. The main idea of using Graham and Harvey survey is due to many reasons, first, the other surveys was applied on big firms only, but Graham and Harvey survey included all types of firms despite of their size and ownership. Second, the study sample used in Graham and Harvey survey was larger than 
other surveys. Third, Graham and Harvey survey included more capital budgeting techniques than the others researchers used (Graham \& Harvey, 2001).

Every company needs to decide where and how to spend its money on major projects that will affect company's financial results for the next periods. Such decisions require investment of considerable amounts of money and resources. Capital budgeting describes the long term planning for making and financing such projects. Capital budgeting techniques include many methods or tools such as: Net Present Value NPV, Payback Period PP, Discounted Payback Period DPP, Accounting Rate of Return ARR, Internal Rate of Return IRR, and Profitability Index PI.

Most of the used capital budgeting models are discounted cash flow models. These models focus on a project's cash inflow and outflows while taking into consideration time value of money (Bhimani et al., 2015).

One of the most important and popular capital budgeting technique is the Net Present Value NPV. The NPV method computes the present value of all expected future cash flows depending on acceptable rate of return. The acceptable rate of return depends on the risk associated with the proposed project and the cost of capital which the firm pays to acquire more capital, this acceptable rate of return is sometimes called the required rate of return or the hurdle rate. The NPV formula equals the discounted cash flows from the project minus the cost of project or investment. If the outcome is positive, we accept the project, and if it is minus we reject the project. When choosing among different projects, mangers should select the one with the greatest net present value (Atrill \& Mclaney, 2015).

Another method of capital budgeting techniques is the Payback period. The payback period refers to the time the project will take to recoup, in the form of cash inflows from operations, the initial amount of money invested in the project. The decision role of the payback period is that we choose the project of lower recoup period. The Payback formula equals the initial amounts invested divided by the annual cash inflow expected. This formula applies when there are equal annual cash inflows. But when annual cash inflow are not equal, we must add up each year's net cash flow until the initial investment is recouped (Proctor, 2012).

The third method is the Accounting Rate of Return ARR. The ARR method is a non-discounted cash flow method, it represent the access in expected average annual operating income divided by the initial required investment. If the ARR is higher than the acceptable rate of return then we accept the project, and in case it's lower than ARR we reject the project.

The fourth method is the Internal Rate of Return IRR. The IRR is the interest rate where the NPV of all cash flows from the project equals zero. The decision role of the IRR is that we accept the project when the IRR exceeds the company's acceptable rate of return, and if IRR is below the acceptable IRR we reject the project (Bhimani et al., 2015).

The fifth method is the Profitability Index PI. The PI is an appraisal technique of the discounted cash flows of the project, where the discounted future cash flows are divided by the initial investment of the project (cash outflows). The decision role of PI is to accept the project when PI ratio equals one or above. The main feature of this method is that PI ignores the size of the project (Atrill \& Mclaney, 2015).

\section{Method}

The primary data needed for the study objectives were collected through a survey questionnaire based on Graham and Harvey survey, 2001. The survey focused on the capital budgeting techniques (10 questions). The study was conducted among the industrial sector in Jordan. The Jordanian industrial sector consists of 66 companies which represent the study sample of this research. The study sample vary in its size and ownership, the study included both large firms and small firms in its survey. The study differentiated between large and small firms through measuring the number of employees that work for it and by the total sales within the defined period of the research study. 51 companies had replied to our survey conducted in the current year 2017, which means that $77 \%$ of the study sample replied to our survey.

The questionnaire has been designed to achieve the aim of the survey. The 5 points likert scale was used, each question consisted a scale of five points as follows: $(0$ refers that the respondents never used any method of the capital budgeting techniques, 1 refers to sometimes it was used, 2 refers to often it was used, 4 refers to almost always it was used, then finally 5 refers to always it was used). The questionnaire then was distributed the Chief Financial Officers CFOs of each industry by hand, and where asked to reply to the 10 questions of the survey (Likert, 1932).

Other Data is collected from secondary sources. Secondary data is collected from articles published by the well-known periodicals, books, and dissertations. 
The Statistical Package for Social Sciences SSPS was applied in analyzing the data received; Statistical Analysis tools include descriptive statistics, mainly frequencies and percentages, were used to analyze the survey (Sekrran, 2003).

\section{Data Analysis and Findings}

The questionnaire survey collected from the 51 companies was analyzed and the following results were derived from it as follows:

Most of the CFOs responded that they always use NPV and Payback Period in their evaluation techniques; 58.6\% of CFOs responded that they always or almost always use NPV; $22.4 \%$ responded that they always or almost always use Payback Period; and $12.3 \%$ responded that they always or almost always use IRR; the remaining used a combination of the Accounting Rate of Return, Profitability Index, and sensitivity analysis, Figure 1, illustrates these results.

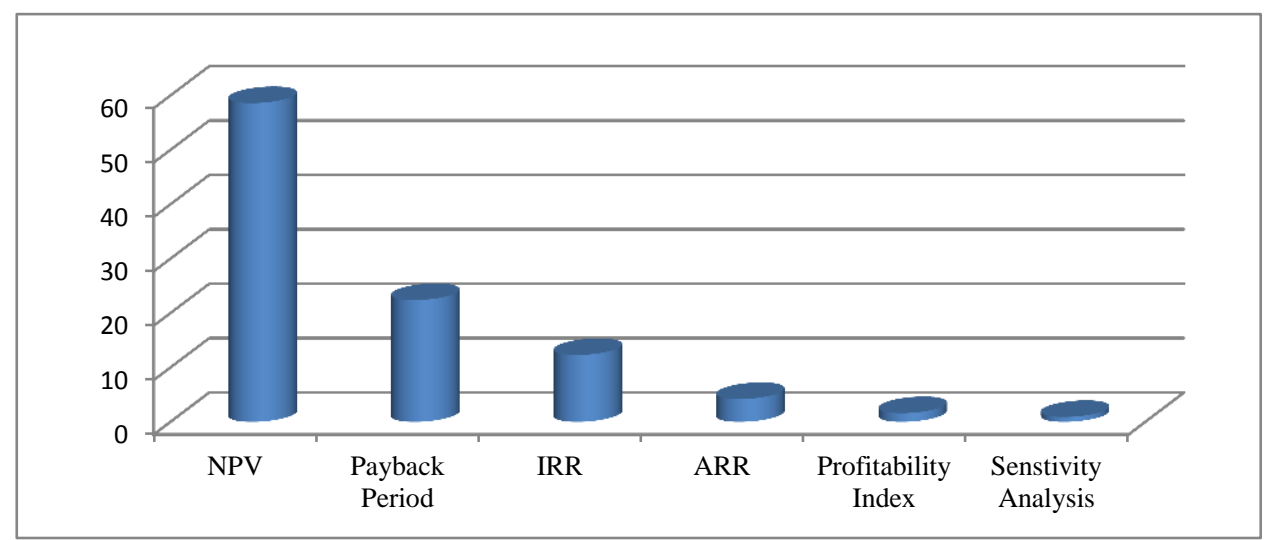

Figure 1. Capital budgeting techniques

The analysis according to the size of the company and the capital budgeting method used, the CFOs of large firms responded as follows; $72.3 \%$ of CFOs responded that they always or almost always use NPV; $12.8 \%$ responded that they always or almost always use Payback Period; and $8.1 \%$ responded that they always or almost always use IRR, and the remaining used a combination of the Accounting Rate of Return, Profitability Index, and sensitivity analysis. Figure 2 illustrates the large firm's responses to their use of the capital budgeting techniques used.

The CFOs of small firms responded as follows; $44.8 \%$ of CFOs responded that they always or almost always use NPV; 32\% responded that they always or almost always use Payback Period; and 16.5\% responded that they always or almost always use IRR, and the remaining used a combination of the Accounting Rate of Return, Profitability Index, and sensitivity analysis. Figure 3 illustrates the small firm's responses to their use of the capital budgeting techniques used.

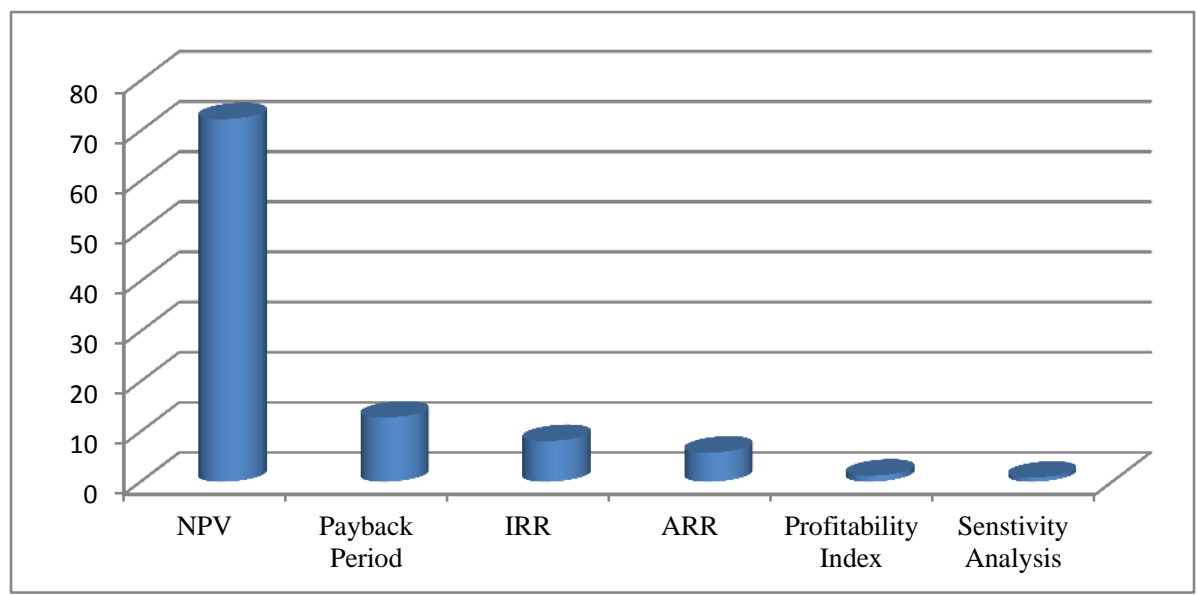

Figure 2. Large firms analysis of using capital budgeting techniques 


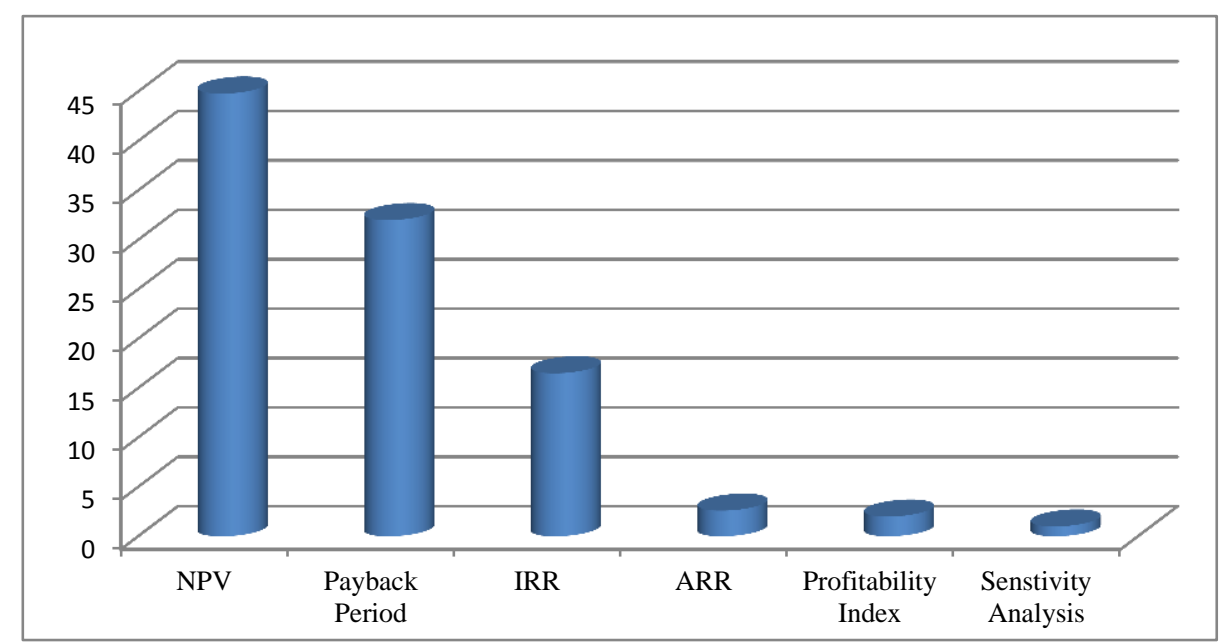

Figure 3. Small firms analysis of using capital budgeting techniques

Table 1 illustrates the total all percentage results of respondent about the capital budgeting techniques used in their companies.

Table 1. Overall capital budgeting techniques percentage results

\begin{tabular}{lcccccc}
\hline Size of Firm & NPV & Payback Period & IRR & ARR & Profitability Index & Sensitivity Analysis \\
\hline All sizes & 58.6 & 22.4 & 12.3 & 4.2 & 1.6 & 0.9 \\
large & 72.3 & 12.8 & 8.1 & 5.8 & 1.2 & 0.8 \\
Small & 44.8 & 32 & 16.5 & 2.6 & 2 & 1 \\
\hline
\end{tabular}

\section{Results}

The general conclusion of study states that, 58\% of Jordanian industrial companies use the Net Present Value, 22\% use the Payback Period, $12 \%$ use the Internal Rate of Return, and the remaining used a combination of the Accounting Rate of Return, Profitability Index, and sensitivity analysis.

The study also revealed that, most of Jordanian industrial companies use NPV as it is considered one the most important method of evaluation techniques, but the detailed analysis according to size of the company revealed that large firms are highly depending on NPV than other methods, the result shows about $72.3 \%$ of large firms are using NPV method, and this can be attributed to the huge investment amounts projected to new projects, and the company want to use a method of high reliability in order to assure the certainty of results and to minimize risk to lowest possible level. The result of the current research paper goes along with results of Barjaktarovic \& others in their research paper carried on the Serbian companies in the year 2016.

As large firms are highly depending on NPV than other methods, the results shows about $44.8 \%$ of small firms are using NPV technique. Small firms are less using NPV technique, and this can be attributed to lower amounts of investment used in their projects, and they are using other methods than NPV, table 1 show that small firms are more likely using Payback Period and IRR than large firms, This result goes along with Andor, Mohanty, \& Toth, study carried on in the year 2011.

As the current research study is expected to assess management in choosing the best capital budgeting technique in the evaluation of its future investment projects, so we expect managers to think of using NPV as their first choice of evaluation technique, and if not possible, then the second choice will be the payback period or the Internal Rate of return IRR.

\section{References}

Andor, G., Mohanty, S., \& Toth, T. (2011). Capital Budgeting Practice: a survey of Central and Eastern European firms. World Bank, Jan, 1-45.

Atrill, \& Mclaney. (2015). Management Accounting for Decision Making (8th ed.). Pearson publishers.

Barjaktarovic, L. et al. (2016). Advancing Serbia's Competitiveness in the Process of EU Accession. Journal of Management. 
Bhimani, Hongren, Datar, \& Rajan. (2015). Cost and Management Accounting (6th ed.). Pearson publishers.

Graham, J., \& Harvey, C. (2001). The Theory and Practice of Corporate finance: Evidence from the field. Journal of Finance Economics, 60, 187-243. https://doi.org/10.1016/S0304-405X(01)00044-7

Likert, R. (1932). A Technique for the Measurement of Attitudes. Archives of Psychology, 22(140), 1-55.

Proctor, R. (2012). Managerial Accounting: Decision making and Performance Improvement (4th ed.). Pearson publishers.

Uma, S. (2003). Research Method for Business: A Skill Building Approach (7th ed.). John Wiley and Sons, New York.

\section{Copyrights}

Copyright for this article is retained by the author(s), with first publication rights granted to the journal.

This is an open-access article distributed under the terms and conditions of the Creative Commons Attribution license (http://creativecommons.org/licenses/by/4.0/). 